\title{
CONTENTS OF ZINC, COPPER AND MANGANESE IN POTATO TUBERS DEPENDING ON THE WAYS OF APPLICATION OF THE SOIL FERTILIZER UGMAX
}

\author{
Alicja Baranowska ${ }^{1}$, Krystyna Zarzecka $^{2}$, Marek Gugała $^{2}$, Iwona Mystkowska ${ }^{1}$ \\ 1 Institute of Agriculture, Pope John II State School of Higher Education in Biala Podlaska, Sidorska 95/98, \\ 21-500 Biała Podlaska, Poland, e-mail: alabar@tlen.pl \\ 2 Department of Agrotechnology, University of Natural Sciences and Humanities in Siedlce, B. Prusa 14, 08-110 \\ Siedlce, Poland
}

Received: 2016.08.17

Accepted: 2016.10 .23

Published: 2017.01.01

\begin{abstract}
The purpose of this study was to determine the influence of the soil fertilizer UGmax on zinc, copper and manganese contents in potato tubers. A three - year field experiment was carried out on soil which belonged to a very good rye complex. The experiment was established according to randomized split-plot method, in three replications. The following factors were examined: factor I: edible potato varieties (Satina and Typhoon), and factor II: doses and timing of UGmax application. As a result of conducted research, significantly smaller copper content in potato tubers was found, after usage of the soil preparation UGmax, in comparison with a control object, while zinc and manganese content continued to show only a downward trend. The influence of weather conditions and potato varieties on the copper cumulation in the dry mass of potato tuber was proved. An important influence of the factors of the experiment on the uptake of researched macroelements with the potato tuber yield was also shown.
\end{abstract}

Keywords: potato, soil fertilizer, copper, zinc, manganese

\section{INTRODUCTION}

According to the data of the Food and Agriculture Organization of The United Nations, potato (Solanum tuberosum L.) is one of the most important plant cultivated in the world [Flis et al., 2012]. Solanum tuberosum L. is a valuable source of many compounds which are important in human diet [Leszczyński, 2000, White and others., 2009]. The nutritional value of potato tubers is closely related to the content and biological quality of the chemical substances. Ware potato tubers contain, on average, $77 \%$ of water, up to $16 \%$ of starch, $0.5 \%$ of sugars, about $2 \%$ of protein, $2.3 \%$ of dietary fibre, about $0.1 \%$ lipids, organic acids, polyphenols, vitamins and also about $1-1.2 \%$ of mineral substances in a form of macro and micronutrients. Macronutrients are elements which are absorbed by plants in relatively large amounts at different stages of maturity. They play important structural and physiological functions.

The demand for micronutrients is smaller but they are as important as macronutrients. These include, inter alia: copper, zinc and manganese. Macronutrients included in many enzymes activate numerous biochemical processes. Their trace amounts are essential to life. The consumption of about $200 \mathrm{~g}$ of potatoes covers from 8 to $15 \%$ of the daily nutritional requirement of our organism for these elements [Roberts, 1981, White et al., 2009, Leszczyński, 2012, Wierzbicka, 2012, Zarzecka et al., 2016].

The soil reaction, proper air humidity, abundance of nutrients and application of microbiological preparations to the soil (the soil fertilizers), are important factors of assimilation of macro and micronutrients. Inoculation of microorganisms improves the soil fertility, plant yielding and chemi- 
cal composition of the tubers [Emitazi et al., 2004, Trawczyński and Bogdanowicz, 2007].

A few empirical findings on the influence of microbiological biopreparations on the content of micronutrients in edible potato tubers as well as on the soil environment, encourage to conducting further research.

The aim of the experiment was to determine the content of copper, zinc and manganese in the tubers and taking them from the potato tubers yield, depending on the ways of applying the soil fertilizer UGmax.

\section{MATERIAL AND METHODS}

A field experiment was carried out at Agricultural Experimental Station in the central Poland $\left(52^{\mathrm{O}} 03^{\mathrm{O}} \mathrm{N} ; 22^{\mathrm{O}} 3^{\circ} \mathrm{E}\right)$. Source material consisted of the results of the three - year field experiment conducted with the usage of the soil fertilizer UGmax, which is an extract of compost containing the vaccine of the soil microorganisms. It consists of: lactic bacteria, bacteria Pseudomonas, Azotobakter, actinomycetes, yeast and macro and micronutrients such as: potassium (3500 $\left.\mathrm{mg} \cdot \mathrm{l}^{-1}\right)$, nitrogen $\left(1200 \mathrm{mg} \cdot \mathrm{l}^{-1}\right)$, sulphur $\left(1000 \mathrm{mg} \cdot \mathrm{l}^{-1}\right)$, phosphorus $\left(500 \mathrm{mg} \cdot \mathrm{l}^{-1}\right)$, sodium $\left(200 \mathrm{mg} \cdot \mathrm{l}^{-1}\right)$, magnesium $\left(100 \mathrm{mg} \cdot \mathrm{l}^{-1}\right)$, zinc $\left(20 \mathrm{mg} \cdot \mathrm{l}^{-1}\right)$, manganese $\left(0.3 \mathrm{mg} \cdot \mathrm{l}^{-1}\right)$ [Trawczyński, 2007].

The experiment was set up on slightly acid and acid soil 4.99-5.91 pH w $1 \mathrm{n} \mathrm{Kcl}$. classified to a quality class IVa, which, according to the Polish classification of the quality of soils, belongs to a very good rye complex, in terms of agricultural usefulness.

Selected chemical properties of the soil are shown in Table 1. The soil was low and medium high in copper, high in zinc, medium in manganese, high and very high in phosphorus, low and medium in potassium, very low and medium in magnesium.

Two-factorial experiment was established according to randomized split-plot method, in three replications. The following factors were examined:

I. Two middle - early edible potato varieties, Satina and Typhoon,

II. Five ways of using the soil fertilizer UGmax at different doses and application time:

1. Control object without UGmax,

2. UGmax applied to the soil before tuber planting at a dose of $1.0 \mathrm{dm}^{3} \cdot \mathrm{ha}^{-1}$,

3. UGmax applied to the soil before tuber planting at a dose of $0.5 \mathrm{dm}^{3} \cdot \mathrm{ha}^{-1}$, when the height of plants is about $10-15 \mathrm{~cm}$, and in the flower buds making phase at a dose of $0.25 \mathrm{dm}^{3} \cdot \mathrm{ha}^{-1}$,

4. UGmax before tuber planting at a dose of $1.0 \mathrm{dm}^{3} \cdot \mathrm{ha}^{-1}$ and when the height of plants is about $10-15 \mathrm{~cm}$ and in the flower buds making phase at a dose of $0.5 \mathrm{dm}^{3} \cdot \mathrm{ha}^{-1}$,

5. UGmax when the height of plants is about $10-15 \mathrm{~cm}$ and in the flower buds making phase at a dose of $0.5 \mathrm{dm}^{3} \cdot \mathrm{ha}^{-1}$. The soil fertilizer was dissolved in $300 \mathrm{dm}^{3}$ of water per hectare.

In the autumn, before the experiment was established, the manure was applied at a dose of 25 $\mathrm{t} \cdot \mathrm{ha}^{-1}$ and phosphorous fertilization $100 \mathrm{~kg} \mathrm{P}_{2} \mathrm{O}_{5}$ as well as potassium $150 \mathrm{~kg} \mathrm{~K}_{2} \mathrm{O}$ were used. In the spring nitrogen fertilization at a dose of 100 $\mathrm{kg} \mathrm{N} \cdot \mathrm{ha}^{-1}$ was applied.

The potato tubers were planted from 10 th to 20 th of April, in a row space of $67.5 \times 37 \mathrm{~cm}$. In order to avoid weed infestation, spraying the mixture of herbicides Command $480 \mathrm{SC} 0.2 \mathrm{dm}^{3} \cdot \mathrm{ha}^{-1}$ + Afalon Dispersive $450 \mathrm{SC} 1.0 \mathrm{dm}^{3} \cdot \mathrm{ha}^{-1}$ was applied. During growing season the plantation

Table 1. Chemical properties of the soil in years of study

\begin{tabular}{|l|c|c|c|}
\hline \multicolumn{1}{|c|}{ Specification } & \multicolumn{2}{c|}{ Years } \\
\hline & 2008 & 2009 & 2010 \\
\hline Soil $\mathrm{pH}(1 \mathrm{M} \mathrm{KCL})$ & 4.99 & 5.15 & 5.91 \\
\hline Organic matter $\left[\mathrm{g}^{\prime} \mathrm{kg}^{-1}\right]$ & 15.40 & 17.80 & 18.10 \\
\hline \multicolumn{2}{|c|}{ Content of available nutrients $\left[\mathrm{mg}^{\prime} \cdot \mathrm{kg}^{-1}\right]$} \\
\hline Copper $(\mathrm{Cu})$ & 2.00 & 1.30 & 2.20 \\
\hline Zinc $(\mathrm{Zn})$ & 7.50 & 7.80 & 7.30 \\
\hline Manganese (Mn) & 8.80 & 100.00 & 80.10 \\
\hline Phosphorus (P) & 90.60 & 95.90 & 73.5 \\
\hline Potassium (K) & 124.50 & 74.70 & 112.10 \\
\hline Magnesium (Mg) & 41.00 & 28.00 & 45.00 \\
\hline
\end{tabular}


was protected against the Colorado potato beetle (Apacz $50 \mathrm{WG}$, Actara $25 \mathrm{WG}$ ) and the potato blight (Ridomil Gold MZ 68 WG, Dithane 455 SC). Tubers were harvested on the first ten days of September,in technological maturity phase.

The content of copper $(\mathrm{Cu})$, zinc $(\mathrm{Zn})$ and manganese (Mn) was determined with the Atomic Absorption Spectrophotometry (AAS) after previous crushing, drying and mineralisation of potato tuber samples in the laboratory furnace at a temperature of $450-550^{\circ} \mathrm{C}$. The results of the study were subjected to the analysis of variance, and the significance of differences was assessed using Tukey's test, at the significance level $\mathrm{p}=$ 0.05 [Ostrowska et al., 1991].

The weather conditions during the study were differential (Table 2). The most beneficial for potato yielding was year 2008 which was marked by evenly distributed rainfall and temperature being similar to the means over a multiannual period. In 2009 rainfall exceeded the average multiannual sum and was unevenly distributed. The average air temperature was higher than multiannual mean. 2010 was the warmest and the wettest year.

\section{RESULTS AND DISCUSSION}

According to many authors, the content of micronutrients in potato tubers depends on the soil $\mathrm{pH}$, its abundance of nutrients, adequate moisture, genetic factors and the use of various types of the soil fertilizers which improve soil properties [Mikos-Bielak and Sawicka, 1992, Prośba-Białczyk and Mydlarski, 2000, Rogóż and Trąbczyńska, 2009, Zarzecka et al., 2016].

Copper is an important component of many plant enzymes and takes part in basic life processes of plants. Excess copper in the diet of humans and animals may result in disorders of the gastrointestinal tract, hemolysis or kidney and liver damage. However, the lack of this micronutrient, hinders the absorption of iron and synthesis of hemoglobin which causes disorders of the cardiovascular system, anaemia and impaired vision [Węglarzy, 2007].

The content of copper in potato tuber dry mass is, on average, $4.0-5.2 \mathrm{mg} \mathrm{kg}^{-1}$ but can vary from 3.0 to $13.7 \mathrm{mg} \mathrm{kg}^{-1}$ [Wierzbicka and Trawczyński 2011, Wierzbicka, 2012]. In our study it was found that copper content in potato tubers ranged from 6.228 to $6.583 \mathrm{mg} \cdot \mathrm{kg}^{-1}$ in dry mass (Tables 3 and 4) and it depended significantly on the ways of applying the soil fertilizer UGmax, cultivated varieties and the weather conditions in the years of the study.

The greatest concentration of this element was observed on the control objects where UGmax preparation was not used. Typhoon variety tubers were characterized by a greater concentration of

Table 2. Weather conditions during potato growing seasons

\begin{tabular}{|c|c|c|c|c|c|c|c|}
\hline \multirow{2}{*}{ Years } & \multicolumn{6}{|c|}{ Months } & \multirow{2}{*}{$\begin{array}{l}\text { Mean/Sum } \\
\text { IV-IX }\end{array}$} \\
\hline & IV & V & VI & VII & VIII & IX & \\
\hline & \multicolumn{7}{|c|}{ Rainfalls (mm) } \\
\hline 2008 & 28.2 & 85.6 & 49.0 & 69.8 & 75.4 & 63.4 & 371.4 \\
\hline 2009 & 8.1 & 68.9 & 145.2 & 26.4 & 80.9 & 24.9 & 354.4 \\
\hline 2010 & 10.7 & 93.2 & 62.6 & 77.0 & 106.3 & 109.9 & 459.7 \\
\hline $\begin{array}{c}\text { The average over } \\
\text { the years } \\
1987-2000\end{array}$ & 38.6 & 44.1 & 52.4 & 49.8 & 43.0 & 47.3 & 275.2 \\
\hline \multicolumn{8}{|c|}{ Temperature $\left({ }^{\circ} \mathrm{C}\right)$} \\
\hline 2008 & 9.1 & 12.7 & 17.4 & 18.4 & 18.5 & 12.2 & 14.7 \\
\hline 2009 & 10.3 & 12.9 & 15.7 & 19.4 & 17.7 & 14.6 & 15.1 \\
\hline 2010 & 8.9 & 14.0 & 17.4 & 21.6 & 19.8 & 11.8 & 15.6 \\
\hline $\begin{array}{c}\text { The average over } \\
\text { the years } \\
1987-2000\end{array}$ & 7.8 & 12.5 & 17.2 & 19.2 & 18.5 & 13.1 & 14.7 \\
\hline \multicolumn{8}{|c|}{ Sielianinov's hydrothermic coefficients } \\
\hline 2008 & 1.04 & 2.18 & 0.94 & 1.25 & 1.36 & 1.73 & 1.39 \\
\hline 2009 & 0.26 & 1.72 & 3.08 & 0.44 & 1.48 & 0.57 & 1.28 \\
\hline 2010 & 0.40 & 2.14 & 1.20 & 1.15 & 1.74 & 3.10 & 1.61 \\
\hline
\end{tabular}

Coefficient value [Bac at al. 1998]: < 0.5 - strong drought; 0.51-0.69- semi drought; 0.70-0.99 - pure drought; $\geq 1$ - fault drought 
Table 3. Content of copper $(\mathrm{Cu})$, zinc $(\mathrm{Zn})$ and manganese $(\mathrm{Mn})$ in dry mass of potato tubers depending on methods of use UGmax and cultivar $\left[\mathrm{mg} \cdot \mathrm{kg}^{-1}\right]$

\begin{tabular}{|c|c|c|c|}
\hline \multirow{2}{*}{ Objects } & \multicolumn{2}{|c|}{ Potato cultivars } & \multirow{2}{*}{ Mean } \\
\hline & Satina & Tajfun & \\
\hline \multicolumn{4}{|c|}{ Copper $(\mathrm{Cu})$} \\
\hline 1. Control & 6.359 & 6.494 & 6.427 \\
\hline 2. UGmax $1.0+0 \mathrm{dm}^{3} \cdot \mathrm{ha}^{-1}$ & 6.302 & 6.410 & 6.356 \\
\hline 3. UGmax $0.5+0.25+0.25 \mathrm{dm}^{3} \cdot \mathrm{ha}^{-1}$ & 6.319 & 6.408 & 6.364 \\
\hline 4. UGmax $1.0+0.25+0.25 \mathrm{dm}^{3} \cdot \mathrm{ha}^{-1}$ & 6.294 & 6.383 & 6.339 \\
\hline 5. UGmax $0+0.5+0.5 \mathrm{dm}^{3} \cdot \mathrm{ha}^{-1}$ & 6.328 & 6.425 & 6.376 \\
\hline Mean & 6.320 & 6.424 & 6.372 \\
\hline $\begin{array}{l}\mathrm{LSD}_{0.05} \text { for: } \\
\text { methods of use UGmax - I } \\
\text { cultivars - II } \\
\text { interaction I x II }\end{array}$ & & & $\begin{array}{c}0.038 \\
0.017 \\
\text { n.s. }\end{array}$ \\
\hline \multicolumn{4}{|c|}{ Zinc $(\mathrm{Zn})$} \\
\hline 1. Control & 20.76 & 21.12 & 20.94 \\
\hline 2. UGmax $1.0+0 \mathrm{dm}^{3} \cdot \mathrm{ha}^{-1}$ & 20.51 & 20.50 & 20.51 \\
\hline 3. UGmax $0.5+0.25+0.25 \mathrm{dm}^{3} \cdot \mathrm{ha}^{-1}$ & 20.36 & 20.55 & 20.46 \\
\hline 4. UGmax $1.0+0.25+0.25 \mathrm{dm}^{3} \cdot \mathrm{ha}^{-1}$ & 20.21 & 20.49 & 20.35 \\
\hline 5. UGmax $0+0.5+0.5 \mathrm{dm}^{3} \cdot \mathrm{ha}^{-1}$ & 20.43 & 20.70 & 20.57 \\
\hline Mean & 20.45 & 20.67 & 20.57 \\
\hline $\begin{array}{l}\mathrm{LSD}_{0.05} \text { for: } \\
\text { methods of use UGmax - I } \\
\text { cultivars - II } \\
\text { interaction I x II }\end{array}$ & & & $\begin{array}{l}\text { n.s. } \\
\text { n.s. } \\
\text { n.s. }\end{array}$ \\
\hline \multicolumn{4}{|c|}{ Manganese $(\mathrm{Mn})$} \\
\hline 1. Control & 22.36 & 22.11 & 22.24 \\
\hline 2. UGmax $1.0+0 \mathrm{dm}^{3} \cdot \mathrm{ha}^{-1}$ & 22.12 & 21.81 & 21.97 \\
\hline 3. UGmax $0.5+0.25+0.25 \mathrm{dm}^{3} \cdot \mathrm{ha}^{-1}$ & 21.92 & 21.51 & 21.72 \\
\hline 4. UGmax $1.0+0.25+0.25 \mathrm{dm}^{3} \cdot \mathrm{ha}^{-1}$ & 21.49 & 21.24 & 21.37 \\
\hline 5. UGmax $0+0.5+0.5 \mathrm{dm}^{3} \cdot \mathrm{ha}^{-1}$ & 22.13 & 21.62 & 21.88 \\
\hline Mean & 22.01 & 21.66 & 21.83 \\
\hline $\begin{array}{l}\mathrm{LSD}_{0.05} \text { for: } \\
\text { methods of use UGmax - I } \\
\text { cultivars - II } \\
\text { interaction I x II }\end{array}$ & & & $\begin{array}{l}\text { n.s. } \\
\text { n.s. } \\
\text { n.s. }\end{array}$ \\
\hline
\end{tabular}

n.s. - not significant at $\mathrm{P}_{0.05}$

this component than Satina variety, which points to a great influence of varietal characteristics. The copper content in tubers was significantly differentiated by weather conditions during the growing season. The largest amount of this component was recorded in 2008, when weather conditions were most favourable to the growth and development of potato plants. Similar test results reported Arvin et al. [2005] and Manzell et al. [2010].

One of the most important micronutrients is zinc, which takes part in the metabolism of carbohydrates, proteins, and phosphorus compounds. It also regulates the formation of ribosomes, auxin, cellular components and increases plant resistance against drought and diseases [Leszczyński, 2012]. As a result of the study it was found that zinc content in potato tubers ranged from 19.79 to $21.34 \mathrm{mg} \cdot \mathrm{kg}^{-1}$ in dry mass (Tables 3 and 4). Typhoon tubers collected more of this element(on average $20.76 \mathrm{mg} \cdot \mathrm{kg}^{-1}$ in dry mass than Satina variety (on average $20.45 \mathrm{mg} \cdot \mathrm{kg}^{-1}$ in dry mass), but these differences were not statistically confirmed. Different test results obtained Flis et al. [2012], who showed that the ability to collecting micronutrients in potato tubers is a genetic trait, which depends on the variety.

While comparing the zinc content in tubers it was observed that treatments with UGmax helped to reduce the concentration of this micronutrient, in comparison with potatoes collected from the control object, but the differences were insignificant. In our study, no significant influence of weather conditions on the zinc content in potato tubers was shown, but greater concentration of 
Table 4. Content of copper $(\mathrm{Cu})$, zinc $(\mathrm{Zn})$ and manganese $(\mathrm{Mn})$ in potato tubers depending on weather conditions in years of study $[\mathrm{mg} \cdot \mathrm{kg}-1]$

\begin{tabular}{|c|c|c|c|c|}
\hline \multirow{2}{*}{ Objects } & \multicolumn{3}{|c|}{ Years } & \multirow[t]{2}{*}{ Mean } \\
\hline & 2008 & 2009 & 2010 & \\
\hline \multicolumn{5}{|c|}{ Copper $(\mathrm{Cu})$} \\
\hline 1. Control & 6.583 & 6.353 & 6.344 & 6.427 \\
\hline 2. UGmax $1.0+0 \mathrm{dm}^{3} \cdot \mathrm{ha}^{-1}$ & 6.519 & 6.300 & 6.250 & 6.256 \\
\hline 3. UGmax $0.5+0.25+0.25 \mathrm{dm}^{3} \cdot \mathrm{ha}^{-1}$ & 6.554 & 6.295 & 6.242 & 6.364 \\
\hline 4. UGmax $1.0+0.25+0.25 \mathrm{dm}^{3} \cdot \mathrm{ha}^{-1}$ & 6.534 & 6.255 & 6.228 & 6.339 \\
\hline 5. UGmax $0+0.5+0.5 \mathrm{dm}^{3} \cdot \mathrm{ha}^{-1}$ & 6.567 & 6.302 & 6.260 & 6.376 \\
\hline Mean & 6.551 & 6.301 & 6.265 & 6.372 \\
\hline $\begin{array}{l}\text { LSD }{ }_{0.05} \text { for: } \\
\text { methods of use UGmax - I } \\
\text { years - II } \\
\text { interaction I x II }\end{array}$ & & & & $\begin{array}{c}0.038 \\
0.025 \\
\text { n.s. }\end{array}$ \\
\hline \multicolumn{5}{|c|}{ Zinc $(Z n)$} \\
\hline 1. Control & 20.35 & 21.34 & 21.13 & 20.94 \\
\hline 2. UGmax $1.0+0 \mathrm{dm}^{3} \cdot \mathrm{ha}^{-1}$ & 19.89 & 21.12 & 20.52 & 20.51 \\
\hline 3. UGmax $0.5+0.25+0.25 \mathrm{dm}^{3} \cdot \mathrm{ha}^{-1}$ & 19.79 & 21.09 & 20.49 & 20.46 \\
\hline 4. UGmax $1.0+0.25+0.25 \mathrm{dm}^{3} \cdot \mathrm{ha}^{-1}$ & 19.82 & 20.92 & 20.32 & 20.35 \\
\hline 5. UGmax $0+0.5+0.5 \mathrm{dm}^{3} \cdot \mathrm{ha}^{-1}$ & 19.90 & 21.14 & 20.67 & 20.57 \\
\hline Mean & 19.95 & 21.12 & 20.63 & 20.57 \\
\hline $\begin{array}{l}\text { LSD }{ }_{0.05} \text { for: } \\
\text { methods of use UGmax - I } \\
\text { years - II } \\
\text { interaction I x II }\end{array}$ & & & & $\begin{array}{l}\text { n.s. } \\
\text { n.s. } \\
\text { n.s. }\end{array}$ \\
\hline \multicolumn{5}{|c|}{ Manganese $(\mathrm{Mn})$} \\
\hline 1. Control & 22.58 & 22.67 & 21.47 & 22.24 \\
\hline 2. UGmax $1.0+0 \mathrm{dm}^{3} \cdot \mathrm{ha}^{-1}$ & 22.52 & 22.40 & 20.99 & 21.97 \\
\hline 3. UGmax $0.5+0.25+0.25 \mathrm{dm}^{3} \cdot \mathrm{ha}^{-1}$ & 22.35 & 22.24 & 20.57 & 21.72 \\
\hline 4. UGmax $1.0+0.25+0.25 \mathrm{dm}^{3} \cdot \mathrm{ha}^{-1}$ & 21.78 & 21.85 & 20.47 & 21.37 \\
\hline 5. UGmax $0+0.5+0.5 \mathrm{dm}^{3} \cdot \mathrm{ha}^{-1}$ & 21.97 & 22.45 & 21.22 & 21.88 \\
\hline Mean & 22.24 & 22.32 & 20.94 & 21.83 \\
\hline $\begin{array}{l}\mathrm{LSD}_{0.05} \text { for: } \\
\text { methods of use UGmax - I } \\
\text { years - II } \\
\text { interaction I x II }\end{array}$ & & & & $\begin{array}{l}\text { n.s. } \\
\text { n.s. } \\
\text { n.s. }\end{array}$ \\
\hline
\end{tabular}

n.s. - not significant at $\mathrm{P}_{0.05}$

this element was observed in 2009, which was a warm year with unevenly distributed rainfall and the soil was acidic (pH 5.15), which is in line with the studies of Nowacki [2010], who stated that the $\mathrm{pH}$ of the soil is an important factor in the absorption of macro and micronutrients.

Manganese plays many roles in plants, it takes part in the photosynthesis process, biosynthesis of vitamin $\mathrm{C}$, transformations of nitrogen compounds. It also influences the absorption of phosphorus and iron from the soil. In human organism it is responsible for the absorption of vitamins, carbohydrate metabolism, lipids and the correct work of the brain [Jędrzejczak, 2004]. In our study we found that manganese content in potato tubers ranged from 20.47 to 22.67 $\mathrm{mg} \cdot \mathrm{kg}^{-1}$ in dry mass (tab. 3-4), which is consistent with the findings of Ciećko and Wyszkowski [2000]. The concentration of this component in the tubers was not significantly varied by the experimental factors. Only tendency to reduction of the manganese content was observed after usage of UGmax, in comparison with the control object. What is more, the varieties did not differ significantly in terms of the feature discussed. However, Arvin et al. [2005], Wierzbicka and Trawczyński [2011] showed the influence of the variety on manganese content in potato tubers. In our study, no significant effect of weather conditions on the manganese content in potato tubers was observed, but greater concentration of this element was noticed in 2009. 
The uptake of $\mathrm{Cu}, \mathrm{Zn}$ and $\mathrm{Mn}$ with potato tubers yield depended on the ways of UGmax application and varieties of the potato, whereas uptake of copper and manganese also on the thermal and moisture conditions in the years of the study (Tables 5 and 6). Significantly bigger uptake of these components was observed on objects 3 and 4 where spraying with preparation UGmax was used three times, at different doses and time of application. Greater uptake of tested components was noticed in Typhoon variety than in Satina. Significant influence of the weather conditions on the uptake of $\mathrm{Cu}$ and $\mathrm{Mn}$ in the years of the study was proved. The uptake of tested micronutrients, with the potato tuber yield, was the great- est in 2008 which was the most favourable year for growth and vegetation of potato plants. The influence of interaction between the methods of usage of UGmax preparation, as well as varieties and the weather conditions, on copper and manganese uptake was demonstrated.

\section{CONCLUSIONS}

1. After the usage of the soil fertilizer UGmax, significantly smaller copper content in potato tubers, in comparison with the control object, was found. Whereas zinc and manganese content showed only a declining tendency.

Table 5. Uptake of copper $(\mathrm{Cu})$, zinc $(\mathrm{Zn})$ and manganese $(\mathrm{Mn})$ with the yield of potato tubers depending on methods of use UGmax $\left[\mathrm{g} \cdot \mathrm{ha}^{-1}\right]$

\begin{tabular}{|c|c|c|c|}
\hline \multirow{2}{*}{ Objects } & \multicolumn{2}{|c|}{ Potato cultivars } & \multirow{2}{*}{ Mean } \\
\hline & Satina & Tajfun & \\
\hline \multicolumn{4}{|c|}{ Copper $(\mathrm{Cu})$} \\
\hline 1. Control & 34.37 & 56.13 & 45.25 \\
\hline 2. UGmax $1.0+0 \mathrm{dm}^{3} \cdot \mathrm{ha}^{-1}$ & 44.25 & 68.85 & 56.55 \\
\hline 3. UGmax $0.5+0.25+0.25 \mathrm{dm}^{3} \cdot \mathrm{ha}^{-1}$ & 47.60 & 70.54 & 59.08 \\
\hline 4. UGmax $1.0+0.25+0.25 \mathrm{dm}^{3} \cdot \mathrm{ha}^{-1}$ & 52.92 & 80.94 & 66.93 \\
\hline 5. UGmax $0+0.5+0.5 \mathrm{dm}^{3} \cdot \mathrm{ha}^{-1}$ & 38.84 & 62.99 & 50.92 \\
\hline Mean & 43.60 & 67.89 & 55.75 \\
\hline $\begin{array}{l}\mathrm{LSD}_{0.05} \text { for: } \\
\text { methods of use UGmax - I } \\
\text { cultivars - II } \\
\text { interaction I x II }\end{array}$ & & & $\begin{array}{l}1.97 \\
1.63 \\
1.97\end{array}$ \\
\hline \multicolumn{4}{|c|}{ Zinc $(Z n)$} \\
\hline 1. Control & 111.20 & 180.30 & 145.70 \\
\hline 2. UGmax $1.0+0 \mathrm{dm}^{3} \cdot \mathrm{ha}^{-1}$ & 142.60 & 216.60 & 179.60 \\
\hline 3. UGmax $0.5+0.25+0.25 \mathrm{dm}^{3} \cdot \mathrm{ha}^{-1}$ & 152.50 & 230.10 & 191.30 \\
\hline 4. UGmax $1.0+0.25+0.25 \mathrm{dm}^{3} \cdot \mathrm{ha}^{-1}$ & 167.90 & 250.70 & 209.30 \\
\hline 5. UGmax $0+0.5+0.5 \mathrm{dm}^{3} \cdot \mathrm{ha}^{-1}$ & 123.80 & 200.30 & 162.10 \\
\hline Mean & 139.60 & 215.60 & 177.60 \\
\hline $\begin{array}{l}\mathrm{LSD}_{0.05} \text { for: } \\
\text { methods of use UGmax - I } \\
\text { cultivars - II } \\
\text { interaction I x II }\end{array}$ & & & $\begin{array}{l}2.9 \\
2.6 \\
\text { n.s. }\end{array}$ \\
\hline \multicolumn{4}{|c|}{ Manganese $(\mathrm{Mn})$} \\
\hline 1. Control & 12.14 & 19.09 & 15.62 \\
\hline 2. UGmax $1.0+0 \mathrm{dm}^{3} \cdot \mathrm{ha}^{-1}$ & 15.58 & 22.62 & 19.10 \\
\hline 3. UGmax $0.5+0.25+0.25 \mathrm{dm}^{3} \cdot \mathrm{ha}^{-1}$ & 16.52 & 24.41 & 20.46 \\
\hline 4. UGmax $1.0+0.25+0.25 \mathrm{dm}^{3} \cdot \mathrm{ha}^{-1}$ & 18.07 & 27.81 & 22.95 \\
\hline 5. UGmax 0+0.5+0.5 dm $\mathrm{dm}^{3} \cdot \mathrm{ha}^{-1}$ & 13.54 & 21.06 & 17.30 \\
\hline Mean & 15.17 & 23.00 & 19.09 \\
\hline $\begin{array}{l}\mathrm{LSD}_{0.05} \text { for: } \\
\text { methods of use UGmax - I } \\
\text { cultivars - II } \\
\text { interaction I x II }\end{array}$ & & & $\begin{array}{l}1.21 \\
0.96 \\
1.21\end{array}$ \\
\hline
\end{tabular}

n.s. - not significant at $\mathrm{P}_{0.05}$ 
Table 6. Uptake of copper $(\mathrm{Cu})$, zinc $(\mathrm{Zn})$ and manganese $(\mathrm{Mn})$ with the yield of potato tubers depending on weather conditions in years of study $\left[\mathrm{g} \cdot \mathrm{ha}^{-1}\right]$

\begin{tabular}{|c|c|c|c|c|}
\hline \multirow{2}{*}{ Objects } & \multicolumn{3}{|c|}{ Years } & \multirow[t]{2}{*}{ Mean } \\
\hline & 2008 & 2009 & 2010 & \\
\hline \multicolumn{5}{|c|}{ Copper $(\mathrm{Cu})$} \\
\hline 1. Control & 65.28 & 36.88 & 33.59 & 45.25 \\
\hline 2. UGmax $1.0+0 \mathrm{dm}^{3} \cdot \mathrm{ha}^{-1}$ & 84.80 & 43.90 & 40.96 & 56.55 \\
\hline 3. UGmax $0.5+0.25+0.25 \mathrm{dm}^{3} \cdot \mathrm{ha}^{-1}$ & 84.06 & 50.15 & 43.02 & 59.08 \\
\hline 4. UGmax $1.0+0.25+0.25 \mathrm{dm}^{3} \cdot \mathrm{ha}^{-1}$ & 94.18 & 57.68 & 48.94 & 66.93 \\
\hline 5. UGmax $0+0.5+0.5 \mathrm{dm}^{3} \cdot \mathrm{ha}^{-1}$ & 73.66 & 41.00 & 38.09 & 50.92 \\
\hline Mean & 80.40 & 45.92 & 40.92 & 55.75 \\
\hline $\begin{array}{l}\text { LSD }{ }_{0.05} \text { for: } \\
\text { methods of use UGmax - I } \\
\text { years - II } \\
\text { interaction I x II } \\
\end{array}$ & & & & $\begin{array}{l}1.97 \\
2.50 \\
3.42 \\
\end{array}$ \\
\hline \multicolumn{5}{|c|}{ Zinc (Zn) } \\
\hline 1. Control & 201.30 & 123.50 & 112.30 & 145.70 \\
\hline 2. UGmax $1.0+0 \mathrm{dm}^{3} \cdot \mathrm{ha}^{-1}$ & 257.30 & 147.10 & 134.50 & 179.60 \\
\hline 3. UGmax $0.5+0.25+0.25 \mathrm{dm}^{3} \cdot \mathrm{ha}^{-1}$ & 253.20 & 169.10 & 151.70 & 191.30 \\
\hline 4. UGmax $1.0+0.25+0.25 \mathrm{dm}^{3} \cdot \mathrm{ha}^{-1}$ & 282.10 & 186.20 & 159.70 & 209.30 \\
\hline 5. UGmax $0+0.5+0.5 \mathrm{dm}^{3} \cdot \mathrm{ha}^{-1}$ & 222.90 & 137.30 & 126.00 & 162.10 \\
\hline Mean & 243.40 & 15.70 & 136.80 & 177.60 \\
\hline $\begin{array}{l}\text { LSD }_{0.05} \text { for: } \\
\text { methods of use UGmax - I } \\
\text { years - II } \\
\text { interaction I x II }\end{array}$ & & & & $\begin{array}{l}2.9 \\
\text { n.s. } \\
\text { n.s. }\end{array}$ \\
\hline \multicolumn{5}{|c|}{ Manganese $(\mathrm{Mn})$} \\
\hline 1. Control & 22.32 & 13.11 & 11.42 & 15.62 \\
\hline 2. UGmax $1.0+0 \mathrm{dm}^{3} \cdot \mathrm{ha}^{-1}$ & 29.17 & 14.43 & 13.71 & 19.10 \\
\hline 3. UGmax $0.5+0.25+0.25 \mathrm{dm}^{3} \cdot \mathrm{ha}^{-1}$ & 28.56 & 17.63 & 15.20 & 20.46 \\
\hline 4. UGmax $1.0+0.25+0.25 \mathrm{dm}^{3} \cdot \mathrm{ha}^{-1}$ & 31.28 & 21.48 & 16.08 & 22.95 \\
\hline 5. UGmax $0+0.5+0.5 \mathrm{dm}^{3} \cdot \mathrm{ha}^{-1}$ & 24.50 & 14.55 & 12.86 & 17.30 \\
\hline Mean & 27.17 & 16.24 & 13.85 & 19.09 \\
\hline $\begin{array}{l}\text { LSD }_{0.05} \text { for: } \\
\text { methods of use UGmax - I } \\
\text { years - II } \\
\text { interaction I x II } \\
\end{array}$ & & & & $\begin{array}{l}1.21 \\
1.48 \\
2.10 \\
\end{array}$ \\
\hline
\end{tabular}

n.s. - not significant at P0.05

2. Typhoon tubers were characterised by a greater concentration of manganese and copper, whereas greater concentration of manganese was found in Satina tubers.

3. The uptake of copper, zinc and manganese with potato tubers yields was shaped by the ways of application of the UGmax preparation and varieties of the potato. The uptake of copper and manganese were also determined by climatic conditions in the years of the studies.

\section{REFERENCES}

1. Arvin M.J., Habib A., Donell D.J., 2005. Effect of calcium concentration in medium on microtuberization of potato (Solanum tuberosum L.). Iran. J. Biotech. 3(3), 152-156.
2. Bac S., Koźmiński Cz., Rojek M., 1998. Agrometeorology. PWN, Warszawa.

3. Ciećko Z., Wyszkowski M. 2000. Effect of NPK and magnesium fertilization on the content of micronutrients (Fe, $\mathrm{Cu}, \mathrm{Zn}, \mathrm{Mn}$ ) in potato tubers. Zesz. Probl. Post. Nauk Rol., 471: 197-204.

4. Emitazi G., Nader A., Etemadifar Z., 2004. Effect of nitrogen fixing bacteria on growth of potato tubers. Adv. Food Sci. 26(2), 56-58.

5. Flis B., Zimnoch-Guzowska E., Mańkowski D., 2012. Correlations among yield, taste, tuber characteristics and mineral contents of potato cultivars grown at different growing conditions. Journal of Agricultural Science. 4(7), 197-207.

6. Jędrzejczak R., 2004. Żelazo i mangan w żywności. Rocz. Państ. Zakł. Hig., 55, 13-20.

7. Leszczyński W., 2000. Jakość ziemniaka konsumpcyjnego. Żywność Nauka Technologia Jakość 4, 5-27. 
8. Leszczyński W., 2012. Żywieniowa wartość ziemniaka i przetworów ziemniaczanych (Przegląd literatury). Biul. Ins. Hod. Aklim. Rośl. 266, 5-20.

9. Manzelli M., Romagnoli S., Ghisell i L., Benedett ell i S., Palchett i E., Andrenell i L., Vecchio V. 2010. Typicity in potato: Characterization of geographic origin. Ital. J. Agron./Riv. Agron. 5, 61-67.

10. Mikos-Bielak M., Sawicka B. 1992. Zmienność zawartości mikroelementów w bulwach różnych odmian ziemniaków. VII Symp. „Mikroelementy w rolnictwie", Wrocław, 16-17.IX.1990.

11. Nowacki W., 2010. Nawadnianie plantacji ziemniaka $\mathrm{W}$ różnych systemach produkcji. Wyd. IHAR-PIB, 56.

12. Ostrowska A., Gawliński S., Szczubiałkowa Z., 1991. Metody analizy i oceny właściwości gleb i roślin. Inst. Ochr. Środ. Warszawa.

13. Prośba-Białczyk U., Mydlarski M. 2000. Wpływ warunków siedliska i właściwości odmian na zawartość pierwiastków śladowych w bulwach ziemniaka. Biuletyn IHAR 213, 45-53.

14. Roberts HR., 1981. Food safety. Wiley, New York. Chapter 3, 77.

15. Rogóż A. Trąbczyńska K., 2009. Zawartość pierwiastków śladowych w glebach i wybranych roślinach okopowych. Cz. I. Zawartość miedzi i cynku. Cz. II. Zawartość manganu i żelaza. Zesz. Probl. Post. Nauk Rol. 541(2), 353-373.

16. Trawczyński T., Bogdanowicz P., 2007. Wykorzystanie użyźniacza glebowego w aspekcie ekologicznej uprawy ziemniaka. J. Res. Appl. Agric. Eng. 52(4), 94-97.

17. Węglarzy K., 2007. Metale ciężkie - źródła zanieczyszczeń i wpływ na środowisko. Wiad. Zootech. 45(3), 31-38.

18. White, P. J., Bradshaw, J. E., Dale, M. F. B., \& Ramsay, G., 2009. Relationship between yield and mineral concentrations in potato tubers. HortScience, 44(1), 6-11.

19. Wierzbicka A., 2012. Mineral content of potato tubers grown in the organic system their nutritional value and interaction. J. Res. Appl. Agric. Engin. 57(4), 188-192.

20. Wierzbicka A., Trawczyński C., 2011. Effect of irrigation and soil-borne microorganisms on themacro - and micronutrient content in organic potato tubers. Fragm. Agron. 28(4), 139-148.

21. Zarzecka K., Gugała M., Baranowska A., Dołęga H., Sikorska A., 2016. Concentrations of copper, zinc and manganese in potato tubers under the influence of herbicides. J. Elem. 21(1), 259-267. 